\title{
FEMALE ENTREPRENEURSHIP AND EVOLUTION IN SMES IN THE FASHION SYSTEM IN COLOMBIA
}

\section{EMPRENDIMIENTO FEMENINO Y EVOLUCIÓN ESTRATÉGICA DE LAS PYMES EN EL SISTEMA MODA EN COLOMBIA}

\author{
Giuseppe Vanoni Martínez $\mathrm{PhD}^{1}$, Alfonso Omaña Guerrero $\mathrm{PhD}^{2}$
}

Keywords:
Colombia,
fashion sector,
woman's
entrepreneurship,
family
businesses

\begin{abstract}
The fashion industry in Colombia is one of the sectors who are showing an exponential grow in the last times with profits for more than 20.2 billion of colombian pesos, approximately 1.3 million of units sold. Under those perspective, this article will focus on how the female enterprises in the fashion system are developing in recent years with examples from highlights cases where the women have an important role as entrepreneur instead in covid times. For this study, the authors made a selection of three companies from the Colombian fashion system led by women. As a result, it was possible identify that those organizations establish the leader as a collaborator and an important part of a business, as well, justified in his/her works in the way to create and share an innovative value necessary to keep the company into the high standards of competitiveness in local and international market.
\end{abstract}

JEL Code: L26, Z21.

Palabras clave:
Colombia,
empresas
familiares, mujer
empresaria,
sector de la
moda.

Resumen

El sector de la moda en Colombia es uno de los de mayor crecimiento, con ganancias que superaron los 20,2 billones de pesos colombianos, lo que representa aproximadamente 1303 millones de unidades vendidas. Bajo este escenario, este artículo se enfocará en identificar los emprendimientos femeninos en el sistema moda y cómo ellos han evolucionado tomando como ejemplo casos de empresas en donde la mujer ha hecho parte importante de dicha evolución y como han generado estrategias en medio de la crisis

\footnotetext{
${ }^{1}$ Institución Universitaria Politécnico Grancolombiano, Facultad de Sociedad, Cultura y Creatividad Carrera 57\# 3-00 (Colombia).

E-mail: gvanoni@poligran.edu.co

${ }^{2}$ Kansas University, School of Education and Human Sciences, 1122W Campus Rd Lawrence, KS 66045 (United States).

E-mail: alfonsomana@ku.edu
} 
pandémica del COVID-19. Se analizaron tres empresas lideradas por mujeres en el sector sistema moda de Colombia. Como resultado se pudo identificar que las organizaciones estudiadas evidenciaron un liderazgo en el cual el colaborador hace parte importante de un negocio donde la agregación constante e innovadora de valor es necesaria para mantenerse en un sector de alta competitividad local e internacional.

Código JEL: L26, Z21.

\section{INTRODUCCTION}

The literature review allows identify some researches focusing on entrepreneurship in which the men represents a relevant figure as a decision maker who assume the risks involved in the act of entrepreneurship. This historical trend on entrepreneurship field justified in the role of men as a leader with high performance in environments characterized for volatility, uncertainty, complexity, and ambiguity environments [VUCA] (Whiteman, 1998, p. 15) in which he assumes the risks (Heller, 2010). Mainly in Latin America, the presence of women have been released from the business contexts, assigning the household chores and childcare as social responsibility, promoting the sexist reductionist, despite the recent practices are showing the contrary trend (Escandón \&Arias, 2011).

This research is focusing on women as entrepreneur and leader in Colombia, country with a historical tradition in female corporations for more than a hundred years supporting the local economy with over about 600,000 employment opportunities in the Fashion System (Colombia Productiva, 2020). The woman corporations have been differentiating from others basically in the competitiveness level, supported by high standards in qualified and creative workforce. Since 2016, those empowering corporations were projecting a roadmap to reach on 2032 an unprecedent level of exports with $40 \%$ of growth and sales for 27.7 trillion colombian pesos. If this female sector achieves those numbers, as strategic statement, become leaders in the region in the generation of value and their penetration in potential markets as well, and allow to close the gap between textile companies and clothing manufacturers.

On this paper the authors assume as first phase the methodology, followed for the theoretical perspective focusing on entrepreneur and gender, small and medium business and the women in fashion system in Colombia under three cases of study $^{3}$

\section{MATERIALS AND METHODS/ METODOLGHY}

In the methodological perspective the research has as a core the entrepreneurship and family businesses as an approach supported in a process as "observation, description, interpretation and understanding" (RuizOlabuénaga, 2012, p. 13) in which the authors explain the presence of women in the fashion system under the methodological stages purposed by Quivy and Van Campenhoudt (2005):

1. Rupture: Despite to the traps and preconceptions of the lack theoretical core, the breaking off represents the first step in the research process as approach to break the prejudice and false evidence. This step starts with exploratory readings and interviews with opinion leaders who are known as key informants and / or privileged witnesses. This initial phase leads to the research problem.

2. Construction: this stage emerges when the logic of the phenomenon, assumed by the researcher, is clearly explained. If did not exist a structured theoretical framework, is not possible

\footnotetext{
${ }^{3}$ Whose names will be omitted for reasons of confidential request.
} 
achieve a successful result. On this stage the researcher assumes positions that allow understand the object of study in a positivist, constructivist, or other trend.

3. Verification: If the object of study can be verified obtains the level or category of 'scientific'. The act of testing a proposition or statement is called experimentation or testing. This phase involves some process called observation, analysis of information and conclusions.

Likewise, this research is framed from the qualitative approach because try to close the gap between theory and practice through the understanding the reality in order to describe and explain the social phenomena from the different perspectives. For this reason, assume the analysis of experiences from groups, people and documents as well (Flick, 2007). In reference to the interpretive paradigm (Guba and Lincoln, 1994) assumed by the authors is explained into the research problem.

With the purpose to collect the information, the authors applied the semi-structured interview to four key informants and the documentary analysis as well. Those methods allow the process to acquire qualitative data into the following steps: 1) audio interviews, 2) transcription of those audios with a protocol developed by the researchers and 3) documents collected by the organization and other information compiled on the bibliographic review. On the other hand, some constraints to develop the family SMEs perspective are: 1) business under the women direction, 2) Colombian Entrepreneurs, and 3) the SMEs.

\section{LITERATURE REVIEW}

\section{Entrepreneurship and entrepreneurs as a foundation of Smes}

Some research emphasizes the positive relationship between entrepreneurship and development, at the same time that recognize the relation between economic prosperity, the dynamics of the entrepreneurial sector (Arrak, Kaasa \& Varblane, 2020), and their impact in new jobs and innovation (Stam, 2015). Despite the countries with lower gross domestic product (GDP) are showing outstanding entrepreneurial activity, the high level of needs and the limited job opportunities justify the contraction of their economies and promote consequences as a job's lose, poverty and lack opportunities, contrary to other countries with healthy economies and higher levels of wealth and job stability (Wennekers \& Thurik, 1999). Furthermore, the correlation between entrepreneurial activity and economic growth is associated with external factors or environmental mutations as political regulations and their impact in the social and cultural contexts (Lemaire, 1997)

For this reason, the entrepreneur (Acz, 2006) emerges as someone who has the ability to identify opportunities that others failed to recognize (Bosma \& Schutjens,2012). It is the theorical construct more studied since 1980s (Aldrich \& Baker, 1997), on the words of Busenitz, West, Shepherd, Nelson, Chandler \& Zacharakis (2003) it is a definition who remain under construction, justified on the multidisciplinarity perspective (Wiseman \& Skilton, 1999), in the long trip to adapt the different theories of management for multiple understanding and convenience (Bygrave, 1989; Murphy, 2009), hence it has not yet been consolidated (Azqueta, 2017) or "no differentiated and recognized from ontological and epistemological basis" (Pereira, 2007, p. 16), which makes it a fragmented construct (Harrison \& Leitch, 1996, p. 69) and poorly structured (Wiseman \& Skilton, 1999).

Pereira (2007) explains that, given the different ways in which the term can be used, that is, as entrepreneurship, entrepreneur, entrepreneurial spirit and even, as the creation of new companies, he's agree with Dery and Tolouse(1994, p.129) who a few years ago clarified their point of view as "it is still in a previous stage, even to the formation as a theory, that is, in a pre-theoretical phase". In fact, the definition is not clear to the academic community as could be identified in some authors, such as Bridge, (2017); Draycott \& Rae (2011); Láckeus (2017); Peña-Calvo, Cárdenas, Rodríguez and 
Sánchez - Lissen (2015); Pfeilstetter (2011); Shane and Venkataraman (2000).

Nevertheless, the entrepreneurship as a theorical construct was established in business area after the first half of 20th century, with the entrepreneur as a singular person who has an outstanding point of view about the business and life, based on him/her own way to manage, behave, and think. Likewise, this profile includes innovative attitudes such as leadership and creativity skills to encourage others to identify business opportunities. In addition to this idea, the managerial-business criterion of entrepreneur shows the ability to generate innovative procedures to boost actions and responses in other people (Béchard \& Gregoire, 2005).

Authors as Stevenson (1983) \& Timmons (1999) represented the most important approach to the entrepreneur definition because explain it from the entrepreneurial mindset. Those thinkers assumed that the entrepreneurship definition was leveraged in opportunities more than resources and it is justified in two lines of action 1) the mindset in which the entrepreneur create companies based on a business and action plan; 2) entrepreneurs who, as employees, are systematically driving innovation in the production process.

Entrepreneur, as a first definition, appeared in 1775 from the French entrepreneur ${ }^{4}$ by Cantillón ${ }^{5}$ (Pereira, 2007). Thus, definition was adapting to an emerging time as a result of the contributions from many authors (Baumol, 1993; Braudel 1985; Casson, 1991), with different emphasis and meaning, since a person who invests to expect superior economic returns based on the rupture of market rules and the consequent competitive advantages (Porter, 2013) with the purpose to obtain a portion of niche, segment or sector (Schumpeter, 1961). Other evolutionary approaches to the entrepreneur concept shows in the table 1.

\footnotetext{
${ }^{4}$ In Spanish means entrepreneur and according to the Royal Academy of the Language it is who entrepreneur with innovative actions or companies.
}

Table 1.

Evolution of Entrepreneur Definition.

\begin{tabular}{|c|c|}
\hline Author & $\begin{array}{c}\text { Criteria used in its } \\
\text { definition }\end{array}$ \\
\hline $\begin{array}{l}\text { Levington } \\
\text { (1922) }\end{array}$ & $\begin{array}{l}\text { The entrepreneur can be perceived as: private } \\
\text { entrepreneur, a partner, a limited company, a } \\
\text { cooperative society, among others. }\end{array}$ \\
\hline $\begin{array}{l}\text { Elly \& Hess } \\
(1937)\end{array}$ & $\begin{array}{l}\text { People or groups who assume the task to } \\
\text { combine the factors of production under the } \\
\text { business model and keep the organization in } \\
\text { operational mode. }\end{array}$ \\
\hline $\begin{array}{l}\text { Schumpeter } \\
\text { (1942) }\end{array}$ & $\begin{array}{l}\text { The innovative entrepreneur generates a } \\
\text { dynamic imbalance that causes creative } \\
\text { destruction. }\end{array}$ \\
\hline Cole (1959) & $\begin{array}{l}\text { The main activity of the entrepreneur is } \\
\text { increasing the profitability of the business, } \\
\text { through the production and distribution of } \\
\text { goods and services. }\end{array}$ \\
\hline Davids (1963) & Founders of new businesses. \\
\hline $\begin{array}{l}\text { Collins \& Moore } \\
(1970)\end{array}$ & $\begin{array}{l}\text { Make a distinction between those who create } \\
\text { a new private company and who have } \\
\text { business positions within an established one. }\end{array}$ \\
\hline $\begin{array}{l}\text { Brockhaus } \\
\text { (1980) }\end{array}$ & Owner and manager of a business. \\
\hline Drucker (1986) & $\begin{array}{l}\text { An innovator, meanwhile, entrepreneurship } \\
\text { refers to business model. The author makes a } \\
\text { differentiation about the typical confusion } \\
\text { that any small business is an } \\
\text { entrepreneurship, therefore, whoever founds } \\
\text { a business it is not an entrepreneur or an } \\
\text { innovator. }\end{array}$ \\
\hline Pereira (2007) & $\begin{array}{l}\text { The definition of entrepreneur contrast from } \\
\text { others, because it is necessary focus on the } \\
\text { process and development, and not only on } \\
\text { results of the action. Thus, characterize the } \\
\text { entrepreneurial spirit is not about the result } \\
\text { of the entrepreneur's action in the creation of } \\
\text { a company or in the accumulation of capital. } \\
\text { The real distinctive factor is the permanent } \\
\text { innovation. }\end{array}$ \\
\hline Perdomo (2012) & $\begin{array}{l}\text { Innovative person who leads and makes } \\
\text { decisions despite the risks an uses them as a } \\
\text { base to assets the information to starts, } \\
\text { develops and makes a business mature. }\end{array}$ \\
\hline $\begin{array}{l}\text { Global } \\
\text { Entrepreneurship } \\
\text { Monitor (2019) }\end{array}$ & $\begin{array}{l}\text { The entrepreneur is a person with } \\
\text { appreciations and perceptions about a } \\
\text { particular situation that emerge in the context } \\
\text { that surrounds him/her and capture from it an } \\
\text { opportunity of business. }\end{array}$ \\
\hline \multicolumn{2}{|c|}{$\begin{array}{l}\text { Source: } \text { Authors based on Gartner (1988); Pereira } \\
\begin{array}{lll}(2007) ; \quad \text { Perdomo } \quad(2012) \text { and Global }\end{array}\end{array}$} \\
\hline
\end{tabular}

\footnotetext{
${ }^{5}$ Recognized as one of the great thinkers of economics and author of Essai sur la nature du Comerse en general.
} 


\section{Entrepreneur, market, and recognition of opportunities.}

Through the bibliographical review, the authors assume different positions around the entrepreneur definitions. However, Rodriguez \& Jimenez (2005) said that the researchers, especially the economists, have not been interested to respond the question "How does the entrepreneur identify a market opportunity that lead him/her to establish a business?" (Schumpeter, 1912, p.83) in order to destroy the traditional status quo that identify the business dynamic behavior in the last century. Same trend was followed for Venkataraman (1997) who answered the Schumpeter question as "the understanding of how the opportunities to put new goods and services on the market are discovered, created and exploited, by whom and which consequences" (p. 120). In contrast with this perspective Kirzner (1973) and Cassson (1991) characterized the entrepreneurship from the recognition of opportunities, established a few years later by Eckhardt \& Shane (2003).

If we go a few steps behind in this short history, to Kirzner (1973) the essence of entrepreneur is the compentece to identify a market opportunity, supported by the business surveillance to collect the data necessary to open those opportunities. In this aspect, Kizner emphasizes that this ability are focusing in how can be search the information and not simply having it. In this respect, Chabaud and Nigijol (2004) said that the real difficult of seeing an opportunity is unknown what are you looking for, because the idea of opportunity become as a spontaneous and random behavior and dependends on the personal entrepreneur behavior (Chabaud and Nigijol, 2004).

\section{The entrepreneur and the context}

Across the review about the entrepreneur as a theoretical construct, emerge the highlight related with the attributes considered in the literature analysis. Table 2 shows the most outstanding characteristics and trends observed in the recent scientific production developed by relevant authors considered for this research.
Table 2

Entrepreneur attributes. Risk taker

Permanent innovator

\begin{tabular}{ll}
\hline Analytical & Leader \\
\hline Adaptable & Motivated \\
\hline Risk calculator & Sore to success \\
\hline Decided & Pioneer \\
\hline Willing to learn & Proactive \\
\hline Flexible & Resilient \\
\hline Opportunity identifier & Paradigm broker \\
\hline
\end{tabular}

Source: Authors

Despite these characteristics could be highlighted and evidenced by different authors throughout the reviewed literature, some coincidence allows identify a possible pattern of behavior. Pereira (2007) said that it is not possible yet establish a clear profile and a best definition around the entrepreneur. In this address, recent research shows that entrepreneurship and personality are not related, but it is possible identify some attributes from a kind of behavior that characterized the entrepreneur in different circumstances. Those attributes allow the identification of permanent changes in him/her behavior, in so many different contexts. For this reason, some authors assume that the entrepreneur attitude change in what is he/she learned and how is learned (Herrera and Montoya, 2013).

In the same idea, Arrak, Kaasa and Varblane (2020) in a study developed in Germany focused in the entrepreneurial behavior, conclude that the regional cultural context is an important determinant of the entrepreneur action, so in that sense the diversity in the cultural perspectives have different impacts in the different stages of the entrepreneurship.

Likewise, we can highlight that, although the cultural environment is a key (where we can highlight demography as a characteristic, including here gender, formal education [Beugelsdijk, Van Schaik and Arts, 2006], the expertise, level of incomes and personal traits, [Stephan and Pathak, 2016]), can be considered other characteristics of context as an important external conditions in which the entrepreneur 
operates, for example: 1) the social context (Rodríguez \& Jiménez, 2005), 2) the economic context, include the unemployment rate (Bosma \& Shutjens, 2011), 3) the entrepreneurial context (Levie \& Autio, 2008).

\section{Micro and SME's in Colombia}

Law 590 (2000) in Colombia regulates, establishes and encourages the integral development of the three business subtypes in which Micro and SMEs are located: 1) microenterprise with no more than 10 workers and with total assets below 501 minimum wages (COP 980,657 ) monthly, 2) small business with a range between 11 and 50 workers and assets above 501 and less than 5001 minimum wages and, 3) medium-sized company with a range between 51 and 200 workers and total assets between 5001 and 15000 wages minima.

Table 3 shows the participation of Micro and SMEs in the Colombian market according to data provided by the Colombian Association of Micro, Small and Medium Enterprises (ACOPI).

Table 3.

Micro and SME's in the Colombian market.

\begin{tabular}{lc}
\multicolumn{1}{c}{ Variable } & Percentage \\
\hline Micro and SME's Rate & $98 \%$ \\
\hline Employment Rate & $80 \%$ \\
\hline GDP & $40 \%$ \\
\hline Exports & $9.8 \%$ \\
\hline Job positions & 17 millones \\
\hline
\end{tabular}

Source: Author based on ACOPI (2020).

The main productive centers of micro and SMEs are located in the departments of Antioquia, Atlántico, Cundinamarca and Valle del Cauca, and they accumulate about $70 \%$ of national production. These companies carry out activities mainly in sectors such as mining, farms (agriculture, livestock, marketing of raw materials and supplies etc.), food, graphic design, auto parts, footwear, clothing, leather, wood, iron and metal, plastics, chemicals and fabrics (ACOPI, 2020).

Until September 2020, Micro and SMEs achieved performance in production, sales, employment and investment in the following percentage values: 1) employment 29\% (high performance that had not occurred since 2017), 2) Increase in production by $9 \%$ and sales by $11 \%$, data far from the historical average, and 3) investment by $18 \%$ according to ACOPI information (2020). This data is shown in figure 1 .

Figure 1.

Historical data of production, sales, employment, and investment.

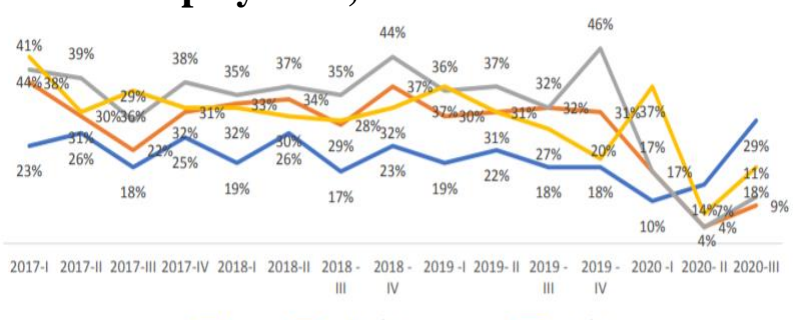

Source: https://www.acopi.org.co/ (2020).

ACOPI values the percentage growth achieved until the end of the third quarter of 2020 as a remarkable performance. It considers that this responds to the adaptations (transformations and replacements) made by employers in jobs due to COVID-19. Likewise, they said that the indicators that showed downward trends were a consequence of the closure of $69 \%$ of the companies due to the announcement of an economic, social and ecological emergency (Decree 417, 2020).

\section{The Colombian Fashion System Sector}

For 2019, the Colombian Fashion System sector represented more than 1,200 companies with contributions of about $9.4 \%$ of GDP. This sector is represented by subsectors such as textiles (fabric manufacturing), apparel (value added to garments) as well as footwear, leather goods and cosmetics (Investincolombia, 2020).

Data for September 2020 allows us to infer that the fashion basket represents about COP 1.87 trillion of the total basket, which means $3.1 \%$ of family spending. Of this percentage, clothing represents $53.50 \%$ of consumption, jewelry $22.10 \%$, footwear $10.30 \%$, clothing services and footwear $8.10 \%$, while home clothing $5.9 \%$. It is relevant that the fashion sector is having constant 
growth since 2017 with COP 22.1 billion, in 2018 COP 22.76 billion while for 2019 with COP 24.26 billion. Despite this, in contrast to September 2019 (COP19.6 trillion), September 2020 (COP 15,87 trillion) shows a decrease close to $-17.2 \%$, although between August and September of this 2020 there was an increase in spending $8 \%$ in fashion (Inexmoda, 2020).

Returning to 2019 data, Colombians bought an average of 29 pieces of clothing, showing Bogotá as the city with the highest rate with $40 \%$ of total consumption, followed by Medellín with $10.8 \%$ and Cali with $8.4 \%$.

The brand strategy most frequently used in the Colombian fashion system is the umbrella brand strategy (or canopy), which means that different sub-brands are added (with different brand names), in order to take the competitive advantage provided by the recognized brand. Therefore, brand extensions or line extensions are very commonly implemented in the fashion sector in Colombia. Additionally, in the strategy of the individual brand, the main brand is not used, for this reason each sub-brand competes in different segments with different brands and without any relationship between the brand and the sub-brand, as a marketing strategy. From these backgrounds arise the question: How are the women-led enterprises have been evolved in the Colombian fashion system sector?

\section{RESULTS}

After analyzing the theoretical components of the research, we proceed to the analysis of field data and documents (Flick, 2007) in particular of the Micro and SMEs selected as key informants or privileged witnesses. It is necessary to inform that the companies studied requested anonymity and confidentiality of data as a condition to participate. For this reason, the results of the investigation refer to the companies as cases 1,2 and 3, while the comments of key informants or privileged witnesses are identified as KI (key informant) 1, 2 and 3. The external expert of the Sector identifies as TP1 (privileged witness 1). Likewise, considering the restrictions indicated in the research method (female organization leader, family business and company of Colombian origin) these are understood in each Micro and SME to study.

\section{Case 1}

The organization has approximately 50 years in the fashion system sector. The CEO says that: "It is not easy to be part of this sector, even more so with the volatility of the commercial context regarding fluctuations in the dollar exchange rates in which we have to live day by day" (IC1). The inputs used for production are imported and the main suppliers are located in Mexico, Brazil and Argentina, countries that use the dollar as currency for commercial transactions.

The organization develops vertical integration as a growth strategy. This process involves weaving, cutting, decoration (includes stamping, sublimation and embroidery), as well as assembly, distribution and delivery. For this reason, they can produce 350,000 units per month, which means 87,500 units per week, 14,500 units per day or 2,000 per hour. The company has established different business models despite the inherent risks (Perdomo, 2012), to break with traditionalism (Venkataraman 1997) and capture different segments. The first segment of interest is the children's market brands, with sales in retail stores and department stores, recognized in Colombia for their high positioning capacity. Also, this segment is considered strategic for international markets in South and Central America, giving priority to markets with natural borders (Casanova, 2015).

The second business model option involves the inclusion of international brands, with global prestige, within the business portfolio. "We have taken this business model because it helps to project our training in the development of smart fabrics with clean processes, as well as an opportunity to apply within the business model" IC1.

"One of the most important things that can be highlighted about our company is, despite being a local company, we have a global philosophy" (TP1). The evolution of the company, with a start 
focused only on the manufacture of children's clothing for small stores in Colombia, currently demonstrates its growth by manufacturing pieces for an important New York brand, which serves medium and luxury segments. "The beginning was a period of trial and error, however we were able to gain the trust of our North American client, in addition to becoming the basis for consolidating our position in this sector in the international market" (IC1). As a result, prestigious brands commissioned them to manufacture clothing for fans of the National Football League (NFL), Major League Soccer (MLS) and National Basketball Association (NBA). Even, North American universities, ranked in the first places, request the manufacture of exclusive products to be purchased in stores on campus and in their stadiums. Successful participation in these markets demonstrates the sore to success in new opportunities (Acz, 2006) where other local companies have not reached.

The prospective vision of the company not only sought to grow locally, it also sought to consolidate a leadership position in the sector in international markets. This purpose drove the organizational evolution inward, when the strategy was focusing on minimizing the typical problems of family businesses and subsequent strategic decision-making. One of these strategies was the standardization of a protocol in which parameters and policies were established with the purpose of clarifying two critical moments in the life of organizations: generational change and changes of authorities. One of the decisions involved the creation of a council with outside members who had managerial expertise in finance and marketing. "With the decision to be part of the international markets, it is necessary to have a healthy organization free from the typical vices of family organizations that allows us to focus on our own growth" (IC1). The decision to formalize the family business also carries an important strategic component at the commercial level, putting the company face to face with strong Asian competitors in the textile sector.

Despite the problems generated by COVID19, the organization stay the course: "The best thing about this crisis has been solidarity" (IC1).
The company was forced to give collective vacations to an approximate payroll of 500 employees, however, one of its most important and great strategic partners in the country advanced the payment, which allowed them to continue working. "We returned to our production work, of course with a change of approach oriented towards the production of surgical masks and aprons, but we were able to do it justified in that none of our employees opposed their return, despite the health crisis".

\section{Case 2}

"Before creating the venture, I had previous steps in other organizations, where I was gaining experience that allowed venturing with this company in the sector" (IC2). The year 2020 began with high expectations, as a consequence of the sustained growth that the organization showed between 2017 and 2019, in addition to the additional benefits that the Colombian fashion system sector showed during that same period (Inexmoda, 2020), with sales in 2019 for more than 9 million units. The remarkable growth in sales in the first quarter of 2020 registered $43 \%$ compared to the same period in 2019, exceeding the estimate by $31 \%$ estimated in the strategic plans. However, the Covid pandemic generated problems in the sales of the company, especially in the month of April, in which sales fell by $70 \%$. "The Covid pandemic made us rethink the business model, for this reason we made strategic decisions that allowed us to evolve in the business towards the present situation" (IC2).

In this context, the company gave priority to sustainability and durability through action plans that make it possible to preserve the budget for payroll and workers. "It was very clear that 2020 would not be a profitable year" (TP1). However, the company made efforts to achieve financial solvency and liquidity in all operations, in addition to keeping employees safe. "We had to take care of human talent as the most important capital of the company. We take care not only of the position. We also take care of the physical, economic and mental health of our workers "(IC2). Another important decision was not to reduce the salary, in order to keep the same staff, 
"they are the ones who add value to our brand" (IC2). Additionally, the company took care of its consumers "the families of the children to whom we focus our products" (IC2). The strategy was designed to provide training and support to generate moments of fun at home, within the same strategic responses of adaptation to the mutations imposed by the context (Lemaire, 1997) in a commercial environment that promoted the relaunch of the portfolio with new products, focused on childcare and strengthening the offer with more comfortable products.

During the evolution of Covid, the organization believed that growth such as brand positioning was possible through industry cooperation and collaboration. The company discovers how necessary stakeholders are for strategic resizing and consider them strategic allies: "we could not leave them alone because 75,000 families depend on the company" (IC2). In addition, more than 50 maquila companies depended on its operations. This framework of strategic thinking served as the basis to support the surrounding society, since they considered that "organizations recognize society as a tangible purpose" (IC2); For this reason, the company gave courses on healthy eating, donated food and other supplies for biosecurity: "We have donated 35 thousand different kinds of products throughout the country" (IC2).

The context of the pandemic allowed an innovation in the supply chain management as part of the response strategy to the pandemic, strengthening the e-commerce channel (to Peru, the United States of America and Bolivia) which in 2019 represented sales only by $8 \%$ and that today represents $20 \%$, although it hurt the sales of established stores. The migration to the digital market created a decrease in the number of points of sale or stores, which justifies that at the end of 2020 there will be 101, four less than December 2019. In general terms, the company expects to reach 7.5 million units, which represents a decrease by $-25 \%$ in the first semester of 2020 and a total decrease to 2020 by $-12 \%$.
Case 3

Company 3 was founded 40 years ago and is located in the Colombian market with 120 stores in Colombia in addition to one in Ecuador and one in Peru, such as natural markets (Casanova, 2015). The strategic approach seeks local growth rather than international growth, with the opening of new stores and a wide variety of products in the portfolio, despite the threat posed by smuggling that affects the footwear and leather market for men and women. The innovation of processes and products is a premise in the evolution of the company (Béchard and Gregoire, 2005), which also develops designs inspired by French fashion.

The organization is characterized by the systematic search for opportunities (Eckhardt and Shane 2003; Minniti, 2012), capturing prospects and retaining clients through "the franchise scheme that leverages these actions" (IC3). In this regard, the company has developed the market towards the motorcycle segment with products such as boots, jackets, gloves and helmets, among other items "taking advantage of the fact that it represents the fastest growing automotive segment in the country" (IC3).

The priority strategy for business development is vertical integration, with footwear, leather goods and leather processing plants, "something that almost does not exist in the country, and we have it" (IC3). The organization is in Armenia and Medellín, developing in the first factory the washing and tanning of the leather while in the second it makes the finishes.

"This period of health crisis has been very complex, the first three months of the Covid pandemic were discouraging, we suffered a $65 \%$ decrease in our sales, only online sales worked somewhat" (IC3). "The organization tried to be consistent with customers" (TP1). In this attempt, some actions were taken to improve clients' finances, such as freezing loans, a measure that sought to compensate for the low bankarization present in the Colombian financial system, due to the reactions of the social environment (Rodríguez and Jiménez, 2005) lived from the 
first quarter of 2020, as a consequence of the unemployment problems that affected the economy (Bosma and Shutjens, 2011). "As an apprenticeship for our brand, we know the new buying culture of consumers, fearful and insecure about leaving home, which is why we must adapt in the best possible way to the new reality." That is why innovation (Drucker) will be the premise on which the organizations and their women as leaders must be consider in the future.

\section{CONCLUSIONS}

As we have been able to observe throughout all the cases analyzed and investigated, it is not clearly established how an entrepreneur is defined, as expressed in the reviewed literature. Although some particularities such as the identification of business opportunities as well as the ability to make decisions in situations related to changes in the environment characterize the entrepreneur, they are considered biased points of view or uncertain approaches.

In relation to the evolution of the entrepreneurs studied, the priority towards the internal organization of the company can be identified as a phase prior to making decisions about geographical expansion or internationalization. When referring to the pandemic, key informants or privileged witnesses show how the entrepreneurial spirit of women argue their decisions to prioritize the health and stability of the employee before the profitability of the company, justified in the action under which the worker is the person who really adds value during the manufacturing process of a product.

\section{LITERATURE REVIEW}

Acs, Z. (2006). How is entrepreneurship good for economic growth? Innovations, Technology, Governance, Globalization, 1(1), 97-107. doi.org/10.1162/itgg.2006.1.1.97.

Aldrich, H. \& Baker, T. (1997). Blinded by the cites? Has there been progress in entrepreneurship research? In D.L. Sexton \& R.W. Smilor (eds.)
Entrepreneurship 2000. Chicago: Upstart Publishing.

Arrak, K, Kaasa, A. \& Varblane, U. (2020). Regional cultural context as a determinant of entrepreneurial behaviour: The Case of Germany. The Journal of Entrepreneurship, 29(1), 1-31. DOI: $10.1177 / 0971355719893501$

Asociación Colombiana de las Micro, Pequeñas y Medianas Empresas. 2020. Revisado el 25 de noviembre. https://www.acopi.org.co/

Azqueta, A. (2017). El concepto de emprendedor: origen, evolución e interpretación. Revisado el 25 de noviembre.

https://idus.us.es/handle/11441/74177

Baumol, W. (1993). The Entrepreneur in economic theory. The American Economic Review. 58(2), 64-71

Beugelsdijk, S., Van Schaik, T. \& Arts, W. (2006). Toward a unified Europe? Explaining regional differences in value patterns by economic development, cultural heritage, and historical shocks. Regional Studies, 40(3), 317327. doi:10.1080/00343400600631590

Bosma, N. \& Schutjens, V. 2011. Understanding regional variation in entrepreneurial activity and entrepreneurial attitude in Europe. The Annals of Regional Science, 47(3), 711-742.

Braudel, F. (1985). Les dynamiques $d u$ capitalisme. Paris: Arthaud.

Bridge, S. (2017). Is entrepreneurship the problem in entrepreneurship education? Education +Training, 59 (7/8): 740-750.

Busenitz, L., West, P., Shepherd, D., Nelson, T., Chandler, G. \& Zacharakis, A. (2003). Entrepreneurship research in emergence: past trends and future directions. Journal of Management, 29(3): 285-308.

Bygrave, W. \& Hofer, Ch. 1991. Theorizing about entrepreneurship. Entrepreneurship Theory and Practice, $16(2)$ 13-22. https://doi.org/10.1177/104225879201600203 
Casanova, L. (2015). Las multinacionales latinoamericanas ante la nueva realidad. En P. Fernández y A. Lluch (Eds.), Familias empresarias y grandes empresas familiares en América Latina y España. Una visión de largo plazo (pp. 71-91). Bilbao: Fundación BBVA.

Casson, M. (1991). L'entrepreneur. Paris: Economica.

Chabaud, D. \& Ngijol, J. (2004). La reconnaissance des opportunités de marche par 1 entrepreneur: faut-il changer de perspective? Association Internationale de Management Stratégique.

Colombia Productiva (2020). ¿Qué es el sector de Sistema Moda? Consultado el 15 de noviembre de 2020. https://bit.ly/3nWiZuS

Defensoria de Colombia. 2000. Ley 590. Revisado el 26 de novienbre https://www.defensoria.gov.co/public/Normogra $\underline{\mathrm{ma} \% 202013 \mathrm{html} / \mathrm{Normas} / \text { Ley 590_2000.pdf }}$

Déry, R. \& Toulouse, J.-M. (1994). La structuration sociale du champs de l'entrepreneurship: le cas du. Journal of Business Venturing, Cahier de recherche 94-06-02.

Draycott, M. \& Rae, D. (2011). Enterprise education in the school and the role of the competency frameworks International Journal of Entrepreneurial Behaviour \& Research, 17(2): 127-145.

Eckhardt, J. \& Shane, S. (2003). Opportunities and Entrepreneurship. Journal of Management, 29(3): 333-349.

Escandón, D. M. \& Arias, A. (2011). Factores que componen la competitividad de las empresas creadas por mujeres y las relaciones entre ellos. Cuadernos de administración, Bogotá (Colombia), 24 (42); 165-181

Flick, U. (2007). Designing qualitative research. Londres - Thousand Oaks - Nueva Delhi Singapur: SAGE.
Guba, E. \& Lincoln, Y. (1994). Competing paradigms in qualitative research. En N. K. Denzin \& Y. Lincoln (Eds.), Handbook of qualitative research (pp. 105-117). Thousand Oaks - Londres - Nueva Delhi: SAGE.

Harrison, R. \& Leitch, C. (2005). Entrepreneurial learning: researching the interface between learning and the entrepreneurial context. Entrepreneurship Theory and Practice, 29(4): 351-371.

Heller, L. (2010). Mujeres emprendedoras en América Latina y el Caribe: realidades, obstáculos y desafíos. Santiago de Chile: Naciones Unidas-CEPAL, División de asuntos de género.

Herrera, C. \& Montoya, L. (2013). El emprendedor: una aproximación a su definición y caracterización. Punto de Vista, 4(7): 7-30.

Inexmoda (2020). Observatorio Sistema moda de septiembre. Recovered from http://www.saladeprensainexmoda.com/wpcontent/uploads/2020/11/Informe-ObservatorioSistema-Moda-Septiembre-2020.pdf

Investincolombia. (2020). Lo que todo inversionista debe saber. Consultado el 26 de noviembre. https://investincolombia.com.co/es

Kirzner, I. (1973). Competition and entrepreneurship. Chicago: Chicago University Press.

Lackéus, M. 2017. Does entrepreneurial education trigger more or less neoliberalism in education? Education + Training, 59(6): 635-650. Lemaire, J. P. (1997). Stratégies d'internationalisation. París: Dunod.

Levie, J \& Autio. E. (2008). A theoretical grounding and test of the GEM model. Small Business Economics, 31(3): 235-263.

Minniti, M. (2012). El emprendimiento y el crecimiento económico de las naciones. Fundamentos y Aspectos Territoriales, 23-30.

Murphy, P. (2009). Entrepreneurship theory and the poverty of historicism. Journal of 
Management History, 15(2): 109-133.

Pfeilstetter, R. (2011). El emprendedor. Una reflexión crítica sobre usos y significados actuales de un concepto, Gazeta de Antropología, 27(1): 111 .

Pereira, F. (2007). La evolución del espíritu emprendedor como campo de conocimiento: una visión sistémica y humanista. Revista Cuadernos de Administración, 20(34): 13-37.

Peña C., Cárdenas A., Rodríguez M. A. \& Sánchez-Lissen, E. (2015). La cultura emprendedora como objetivo educativo: marco general y estado de la cuestión.

L. Núñez Cubero (Coord.). Cultura emprendedora y educación. pp. 19-59. Sevilla, Editorial Universidad de Sevilla.

Porter, M. (2013). Ventaja competitiva. Mexico: Grupo Editorial Patria.

Presidencia de la República de Colombia (2020). Recovered from https://dapre.presidencia.gov.co/normativa/norm ativa/DECRETO\%20417\%20DEL\%2017\%20D E\%20MARZO\%20DE\%202020.pdf

Quivy, R. and Campenhoudt, L. (2005). Manual de investigación en ciencias sociales. Mexico: Limusa.

Rodríguez C. and Jiménez, M. (2005). Emprenderismo, acción gubernamental y academia. Revisión de la literatura. Innovar, 15(26): 73-89.

Ruíz-Olabuénaga, J. (2012). Metodología de la investigación cualitativa. Bilbao: Universidad de Deusto.

Shane, S. (2000). Prior knowledge and the discovery of entrepreneurial opportunities. Organization Science, 11(4): 448-469.

Schumpeter, J. (1912). Théorie de l'Evolution Economique. Paris: Dalloz
Schumpeter, J. (1961). Entrepreneurial profit. In The theory of economic development (pp. 128156). Cambridge: Harvard University Press.

Stephan, U. \& Pathak, S. (2016). Beyond cultural values? Cultural leadership ideals and entrepreneurship. Journal of Business Venturing, 31(5): 505-523.

Perdomo, G. (2012). Análisis del cambio organizacional e institucional. Estudio comparado de dos incubadoras de empresas: "Centro Integral de Servicios Empresariales (CREAME) en Medellín, Colombia (1996- 2010) y Barcelona Activa, en Barcelona, España (1986-2010)". Recuperado de https://repository.eafit.edu.co/bitstream/handle/1 0784/1147/TesisGeovannyPerdomo_2012.pdf;js essionid=FD84ADBBCD26A8DDE49589F62B $\underline{\text { 81DB1D? sequence }=1}$

Stam, E. (2015). Entrepreneurial ecosystems and regional policy: a sympathetic critique. European Planning Studies, 23(9), 1759-1769.

Stevenson, H. (1983). A perspective on entrepreneurship. Cambridge, MA: Harvard Business School.

Timmons, J. (1999). New Venture Creation. Entrepreneurship for the 21st Century. New York: McGraw Hill.

Venkataraman, S. (1997). The distinctive domain of entrepreneurship research: an editor's perspective. In J. Katz and R. Brockhaus (Eds.). Advances in Entrepreneurship, Firm Emergence and Growth, 3 (p.119-138). Greenwich: JAI Press.

Verin, H. (2011). Entrepreneurs, enterprise: histoire d'une idée ( $2^{\mathrm{a}}$ ed). París: Classiques Garnier.

Wennekers, S. \& Thurik, R. (1999). Linking entrepreneurship and economic growth. Small Business Economics, 13(1): 27-56.

Whiteman, W. (1998). Training and educating army officers for the 21st century: Implications for the United States Military Academy. Fort 
Belvoir, VA: Defense Technical Information Center.

Wiseman, R. \& Skilton, P. (1999). Divisions and differences. Journal of Management Inquiry, 8(3): 299-320. 